\title{
Inhibition of Gluconeogenesis and of Cell Respiration by 1-Methyl-4(3-Methyl-5-Isoxazolyl-)Pyridinium Chloride in the Perfused Guinea Pig Liver ${ }^{1}$ )
}

\author{
By R. HAEckei \\ Technical Assistance: U. STREwe \\ Institut für Klinische Chemie (Geschäftsfübrender Direktor: Prof. Dr. Dr. J. Büttner) \\ Medizinische Hochscbule Hannover
}

(Eingegangen am 26. September 1972/12. Januar 1973)

1-Methyl-4-(3-methyl-5-isoxazolyl-)pyridinium chloride, a hypoglycemic compound, has been found to reduce gluconeogenesis from fructose and lactate in the perfused guinea pig liver. All alterations of the pattern of hepatic metabolite concentrations were similiar to those previously observed in the presence of phenylethylbiguanide. Therefore, the same mode of action is suggested for both agents: $A$ decrease of cell respiration leads to an accumulation of reducing equivalents and to a lowered ATP/ADP ratio. Both effects can explain the inhibitory influence of these compounds on pyruvate metabolism and fructose phosphorylation.

1-Methyl-4-(3-methyl-5-isoxazolyl-)pyridiniumchlorid, eine hypoglykämisch wirksame Substanz, hemmt die Gluconeogenese aus Fructose und Lactat in der perfundierten Meerschweinchenleber. Die durch diese Substanz bewirkten Konzentrationsänderungen hepatischer Metabolite gleichen den mit Phenyläthylbiguanid beobachteten. Daher vermuten wir, daß beide Substanzen nach dem gleichen Prinzip wirken: Eine Abnahme der Zellatmung führt zu einer Akkumulierung von Reduktionsäquivalenten und zu einem Absinken des ATP/ ADP-Verhältnisses. Beide Effekte können den hemmenden Einfluß dieser Verbindungen auf den Pyruvatmetabolismus und die Phosphorylierung der Fructose erklären.

Isoxazolylpyridinium salts were found to be a new class of hypoglycemic agents in rats, chicks, mice (1), cockerels and guinea pigs (2). The mode of action of these compounds has not been clarified so far.

Since several hypoglycemic agents are known which reduce hepatic gluconeogenesis (3), we investigated the influence of 1-methyl-4-(3-methyl-5-isoxazolyl-)pyridinium chloride (Fig. 1) on the glucose formation of perfused guinea pig livers. Recently we have reported that this compound decreased gluconeogenesis from lactate (4). The following experiments were performed to gain further insight into the mechanism of the inhibitory effect of 1-methyl-4(3-methyl-5-isoxazolyl-) pyridinium chloride on the hepatic glucose output.

\section{Methods and Materials}

Male, albino guinea pigs (White Pirpright strain, Versuchstierzucht K. H. Peters, D-3255 Lauenau), weighing 300-350 g were fed for 8 days on a standard diet (ssniff, Intermast $\mathrm{GmbH}, \mathrm{D}=463$ Bochum-Hövel), then fasted $48 \mathrm{~h}$ prior to the perfusion experiments.

The perfusion procedure was that of MrLLER et al. (5) and SchIMASSEK (6) as described earlier in detail $(7,8)$. The perfusate

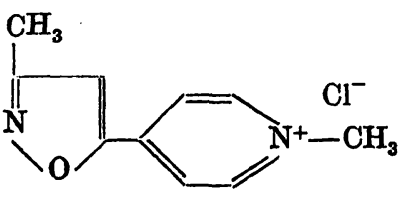

Fig. 1

The structure of 1-methyl-4-(3-methyl-5-isoxazolyl-) pyridinium
$(100 \mathrm{ml})$ contained $30 \mathrm{~g} / \mathrm{l}$ bovine albumin, $10 \mathrm{mg} / 1$ sodium ampicillin and bovine erythrocytes washed three times and taken up in KREBS-RINGER bicarbonate solution (hemoglobin concentration: $50 \mathrm{~g} / \mathrm{l})$. The $\mathrm{pH}$-value measured with an electrode installed in the reservoir was recorded constantly by a $\mathrm{pH}$-meter (type PHM 28, Radiometer Copenhagen) connected to a pointing printer (type NSC, W. H. Joens, D-4 Düsseldorf) and kept constant at $\mathrm{pH} 7.4$ by the addition of sodium bicarbonate. The perfusion experiment lasted $120 \mathrm{~min}$, when $0.3 \mathrm{mmol} / 1$ 1-methyl4-(3-methyl-5-isoxazolyl-)pyridinium chloride and $20 \mathrm{mmol} / 1 \mathrm{lac}-$ tate were used, or $90 \mathrm{~min}$ when $1.5 \mathrm{mmol} / \mathrm{l}$ of this compound and $12 \mathrm{mmol} / 1$ lactate were applied. 1-Methyl-4-(3-methyl-5isoxazolyl-)pyridinium chloride was added to the medium after $45 \mathrm{~min}$, lactate or fructose after $60 \mathrm{~min}$.

Hepatic metabolites were determined enzymatically in perchloric acid extracts of liver samples taken at the end of the perfusion experiments by the method of WOLLENBERGER et al. (9) as reported elsewhere $(7,8)$. Potassium ions were measured by flame photometry (10), calcium and magnesium ions by atomic absorption spectroscopy following the instructions of the manufacturer (model 403 of Perkin-Elmer), phosphate in trichloroacetic acid extracts according to GomorI (11), and hepatic glycogen by the method of KePpLER and DECKER (12).

In all experiments the intracellular concentrations of lactate and fructose were calculated according to НоноRST et al. (13) as follows:

$$
c_{1}=\frac{c_{t}-E \cdot c_{e}}{1-E}
$$

( $c_{1}$ means intracellular concentration, $c_{t}$ tissue concentration, $\mathrm{E}$ extracellular space and $c_{e}$ extracellular concentration). The tissue concentration was determined in perchloric acid extracts. For the

1) Parts of this work have been presented in preliminary form at the 1. European meeting on liver perfusion techniques (4). Supported by the Dcutsche Forschungsgemeinschaft (Bad Godesberg). 
Tab. 1

Experimental conditions for the $\mathrm{CO}_{2}$ - and $\mathrm{O}_{2}$-determination by gaschromatography (Hewlett Packard Research gas-chromatograph 5750)

\begin{tabular}{l|l|l|}
\hline & \\
\hline
\end{tabular}

estimation of the extracellular space inulin was used as reported recently (14).

The $\mathrm{CO}_{2}$ and $\mathrm{O}_{2}$ concentrations in perfusate samples taken from the hepatic in- and outflow (8) were measured by gas chromatography (Tab. 1). A glass loop (15), connected with the injection port by gas valves, contained a reaction chamber $(1-1.5 \mathrm{ml})$ in which a modified VAN SLYKE solution (16) was introduced: solution $\mathrm{A}\left(1.5 \mathrm{~g} \mathrm{~K}_{3} \mathrm{Fe}(\mathrm{CN})_{6}+0.4 \mathrm{~g}\right.$ saponine $+1 \mathrm{ml}$ octanol + bidist. $\mathrm{H}_{2} \mathrm{O}$ to $50 \mathrm{ml}$ ) was mixed with an equal part of solution $B$ $\left(1 \mathrm{ml}\right.$ lactic acid + bidist. $\mathrm{H}_{2} \mathrm{O}$ to $50 \mathrm{ml}$ ) and 1 drop of antifoam prior to use. After the chamber had been closed with a rubber stopper and purged for $3 \mathrm{~min}$ with the carrier gas (helium), the sample $(100 \mu \mathrm{l})$ was injected with a gastight Hamilton syringe. After $2 \mathrm{~min}$ of equilibration the gas valves were opened and the carrier gas allowed to pass through the sample into the columns. Sodium bicarbonate solution ( $12.5 \mathrm{mmolil})$ and pure oxygen gas were used for the calibration. The day-to-day precision (coefficient of variation) of the $\mathrm{CO}_{2}$ determination with acid-base control serum (Versatol) was $2.5 \%(\bar{x}=56.4 ; n=10)$.

All materials for gas chromatography were purchased from Hewlett-Packard (D-703 Böblingen), antifoam from Beckman Instruments (D-8 München) and all other chemicals from Merck AG (D-61 Darmstadt) or as reported earlier (8).

Versatol was bought from Gödecke AG (D-78 Freiburg). 1Methyl-4-(3-methyl-5-isoxazolyl-)pyridinium chloride was a generous gift from Cyanamid GmbH (D-8 München).

\section{Results}

In perfused guinea pig livers glucose formation was reduced to about $50 \%$ by $0.3 \mathrm{mmol} / 1$ 1-methyl-4(3methyl-5-isoxazolyl-)pyridinium chloride and almost completely by $1.5 \mathrm{mmol} / \mathrm{l}$ of this compound (Fig. 2). The hepatic glycogen concentration was significantly $(p<0.05$, t-test $)$ decreased from $1.5 \pm 1.3 \mid(n=10)$ $\mu$ moles/g wet weight to $0.4 \pm 0.3(n=6)$ in livers treated with this compound $(0.3 \mathrm{mmol} / \mathrm{l})$.

When fructose was added to the perfusion medium, 1-methyl-4(3-methyl-5-isoxazolyl-)pyridinium chloride caused a similiar reduction of hepatic glycogen concentration (Tab. 2) and glucose formation (Fig. 3).

In the presence of lactate the pattern of hepatic metabolite concentrations (Tab. 3) did not show clearly where the gluconeogenetic pathway was influenced by 1-methyl-4(3-methyl-5-isoxazolyl-)pyridinium chlo- ride. However, the alterations resembled those observed with phenylethylbiguanide under similiar experimental conditions $(4,8)$ :

1. The concentrations of intrahepatic lactate, pyruvate and acetyl-Co $A$ were increased, whereas those of citrate and 2-oxoglutarate were reduced (Tab. 3).

Tab. 2

The influence of 1-methyl-4(3-methyl-5-isoaxzolyl-)pyridinium chloride $(1.5 \mathrm{mmol} / \mathrm{l}$ ) on hepatic metabolite concentrations ( $\mu$ moles/g liver wet weight with standard deviations and number of contributing values) in the presence of fructose $(15 \mathrm{mmol} / \mathrm{l})$. Perfusion time: $90 \mathrm{~min}$

\begin{tabular}{|c|c|c|}
\hline . & $\begin{array}{l}\text { Controls } \\
\overline{\mathbf{x}} \pm s(n)\end{array}$ & $\begin{array}{c}\text { 1-methyl-4(3-methyl- } \\
\text { 5-isoxazolyl-)pyri- } \\
\text { dinium chloride } \\
\bar{x} \pm s(n)\end{array}$ \\
\hline ATP & $2.11 \pm 0.24(7)$ & $1.45 \pm 0.32(4)$ \\
\hline$A D \check{P}$ & $0.57 \pm 0.06(7)$ & $1.15 \pm 0.11(4)$ \\
\hline ATP/ADP & $3.7 \pm 0.4$ & $1.3 \pm 0.4$ \\
\hline Lactate & $0.53 \pm 0.21(7)$ & $2.02 \pm 0.29(4)$ \\
\hline Pyruvate & $0.05 \pm 0.01(7)$ & $0.13 \pm 0.06(4)$ \\
\hline Lactate/Pyruvate & $12 \pm 6$ & $16 \pm 4$ \\
\hline Fructose?) & $2.91 \pm 1.25(6)$ & $5.31 \pm 1.92(4)$ \\
\hline Fructose-I-phosphate & $2.52 \pm 1.00(6)$ & $\cdot 1.08 \pm 0.30(4)$ \\
\hline $\begin{array}{l}\text { Glyceraldehyde-3- } \\
\text { phosphate }\end{array}$ & $0.02 \pm 0.01(6)$ & $0.02 \pm 0.01(4)$ \\
\hline $\begin{array}{l}\text { Dihydroxyacetone-3- } \\
\text { phosphate }\end{array}$ & $0.05 \pm 0.01(8)$ & $0.03 \pm 0.01(4)$ \\
\hline $\begin{array}{l}\text { Fructose-1,6-di- } \\
\text { phosphate }\end{array}$ & $0.02 \pm 0.01(9)$ & $0.02 \pm 0.01(4)$ \\
\hline Fructose-6-phosphate & $0.04 \pm 0.02(6)$ & $<0.01$ \\
\hline Glucose-6-phosphate & $0.10 \pm 0.04(7)$ & $<0.01$ \\
\hline Glycogen & $1.70 \pm 1.09(5)$ & $3.05 \pm 0.24(4)$ \\
\hline Glycerol & $0.05 \pm 0.04(5)$ & $0.08 \pm 0.04(4)$ \\
\hline Glycerol-3-phosphate & $0.10 \pm 0.03(7)$ & $0.57 \pm 0.11(4)$ \\
\hline
\end{tabular}

a) intrahepatic concentration (corrected for extracellular fructose).

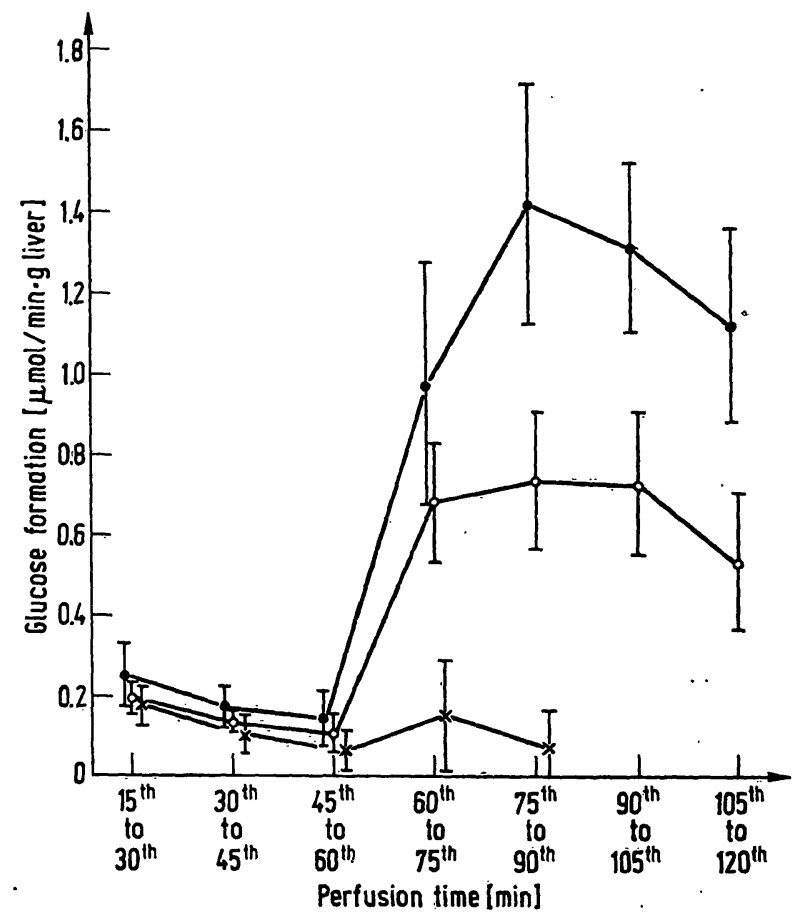

Fig. 2

The influence of 1-methyl-4-(3-methyl-5-isoxazolyl-)pyridinium chloride on glucose formation from lactate in perfused ginea pig livers O- $00.3 \mathrm{mmol} / 1 \mathrm{l}=6), \times-\times 1.5 \mathrm{mmol} / 1 \quad(\mathrm{n}=5) 1-$ methyl-Verticâl bars represent standard deviations 


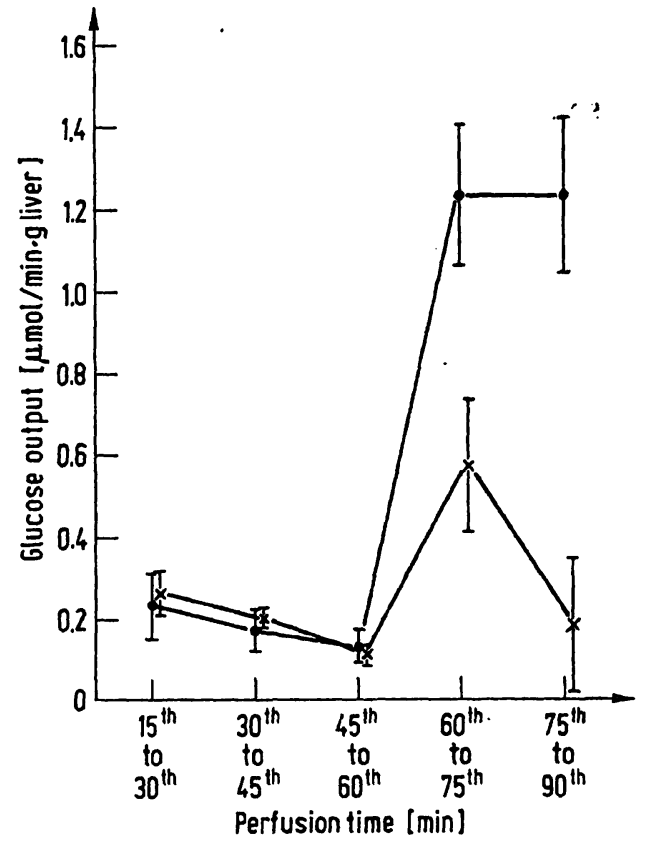

Fig. 3

The effect of 1-methyl-4-(3-methyl-5-isoxazolyl-)pyridinium chloride on the hepatic glucose output in the presence of $15 \mathrm{mmol} / \mathrm{l}$ of fructose $x-x 1.5 \mathrm{mmol} / \mathrm{l}$ 1-methyl-4-(3-methyl-5-isoxazolyl-)pyridinium chloride $(n=4)$,

Tab. 3

The influence of 1-methyl-4(3-methyl-5-isoxazolyl-)pyridinium chloride $(0.3 \mathrm{mmol} / \mathrm{l})$ on hepatic metabolite concentrations ( $\mu$ moles/g liver wet weight with standard deviations and number of contributing values) in the presence of lactate $(20 \mathrm{mmol} / \mathrm{l})$

\begin{tabular}{|c|c|c|}
\hline$\cdot$ & $\begin{array}{l}\text { Controls } \\
\overline{\mathbf{x}} \pm \mathrm{s}(\mathrm{n})\end{array}$ & $\begin{array}{c}\text { 1-methyl-4(3-methyl- } \\
\text { 5-isoxazolyl-)pyri- } \\
\text { dinium chloride } \\
\bar{x} \pm s(n)\end{array}$ \\
\hline Lactate & $i .31 \pm 0.44$ (4) & $3.42 \pm 0.83(4) *$ \\
\hline Pyruvate & $0.18 \pm 0.02(4)$ & $0.22 \pm 0.09(4)$ \\
\hline Acetyl-Co A & $0.03 \pm 0.01(4)$ & $0.05 \pm 0.01(4) *$ \\
\hline Citrate & $0.49 \pm 0.07(5)$ & $0.32 \pm 0.08(5)^{*}$ \\
\hline 2-Oxoglutarate & $0.69 \pm 0.15(5)$ & $0.09 \pm 0.02(5)^{*}$ \\
\hline Malate & $0.52 \pm 0.09(5)$ & $0.95 \pm 0.19(5)$ \\
\hline Phosphoenolpyruvate & $0.26 \pm 0.07(5)$ & $0.25 \pm 0.05(5)$ \\
\hline Glycerate-2-phosphate & $0.08 \pm 0.04(5)$ & $0.07 \pm 0.01(5)$ \\
\hline Glycerate-3-phosphate & $0.70 \pm 0.09(5)$ & $0.84 \pm 0.08(5)$ \\
\hline $\begin{array}{l}\text { Glyceraldehyde-3- } \\
\text { phosphate }\end{array}$ & $0.04 \pm 0.02(5)$ & $0.04 \pm 0.02(4)$ \\
\hline $\begin{array}{l}\text { Dihydroxyacetone-3- } \\
\text { phosphate }\end{array}$ & $0.10 \pm 0.04(4)$ & 0.05 \\
\hline $\begin{array}{l}\text { Fructose-1,6-di- } \\
\text { phosphate }\end{array}$ & $0.03 \pm 0.01(5)$ & $0.02 \pm 0.01(4)$ \\
\hline Fructose-6-phosphate & $0.03 \pm 0.01(6)$ & $0.01 \pm 0.01(4)^{*}$ \\
\hline Glucose-6-phosphate & $0.15 \pm 0.04(5)$ & $0.06 \pm 0.02(4) *$ \\
\hline
\end{tabular}

* These values differ significantly ( $p<0.05, t$-test) from their controls.

2. The hepatic concentration of malate was elevated in relation to the increase of reducing equivalents as shown by the lactate/pyruvate (Tab. 3) and the 3hydroxybutyrate/acetoacetate ratio (Tab. 4).

3. The ratio fructose-1,6-diphosphate to fructose-6phosphate was elevated as was also observed with phenylethylbiguanide (14). This effect was even more pronounced if fructose was used as substrate for gluconeogenesis (Tab. 2).

4. A cross-over phenomenon was caused by 1-methyl4(3-methyl-5-isoxazolyl-)pyridinium chloride between
Tab. 4

The influence of 1-methyl-4(3-methyl-5-isoxazolyl-)pyridinium chloride $(0.3 \mathrm{mmol} / \mathrm{l})$ on the 3-hydroxybutyrate/acetoacetate ratio of the perfused guinea pig liver. Substrate: lactate $(20 \mathrm{mmol} / \mathrm{l})$. The concentrations of metabolites are given in $\mu \mathrm{moles} / \mathrm{g}$ liver wet weight with standard deviation and the number of contributing values

\begin{tabular}{lcc}
\hline & Controls & $\begin{array}{c}\text { 1-methyl-4(3-methyl- } \\
\text { 5-isoxazolyl-)pyri- } \\
\text { dinium chloride } \\
\overline{\mathbf{x}} \pm \mathrm{s}(\mathrm{n})\end{array}$ \\
\hline $\begin{array}{l}\text { 3-Hydroxybutyrate } \\
\begin{array}{l}\text { Acetoacetate } \\
\text { 3-Hydroxybutyrate } \\
\text { + Acetoacetate }\end{array}\end{array}$ & $0.43 \pm 0.13(5)$ & $0.85 \pm 0.19(5)^{*}$ \\
$\begin{array}{l}\text { 3-Hydroxybutyrate/ } \\
\text { Acetoacetate }\end{array}$ & $1.22 \pm 0.26(5)$ & $1.10 \pm 0.30(5)$ \\
\hline
\end{tabular}

* These values differ significantly $(p<0.05)$ from the control result (t-test)

Tab. 5

The influence of 1-methyl-4(3-methyl-5-isoxazolyl-)pyridinium chloride ( $0.3 \mathrm{mmol} / \mathrm{l})$ on ATP/ADP ratio, oxygen consumption and $\mathrm{CO}_{2}$ production of perfused guinea pig livers. Substrate: Lactate $(20 \mathrm{mmol} / \mathrm{l})$

\begin{tabular}{lcc}
\hline & Controls & $\begin{array}{c}\text { 1-methyl-4(3-methyl-5- } \\
\text { isoxazolyl-)pyridinium } \\
\text { chloride } \\
\overline{\mathrm{x}} \pm \mathrm{s}(\mathrm{n})\end{array}$ \\
\hline $\mathrm{ATP}$ & $\overline{\mathrm{x}} \pm \mathrm{s}(\mathrm{n})$ & $1.73 \pm 0.23(5)^{*}$ \\
$\mathrm{ADP}$ & $\left.2.42 \pm 0.21(4)^{\mathrm{a}}\right)$ & $1.29 \pm 0.11(5)^{*}$ \\
ATP/ADP & $\left.0.77 \pm 0.06(4)^{\mathrm{a}}\right)$ & $1.34 \pm 0.29(5)^{*}$ \\
$\mathrm{CO}_{2}$ & $3.15 \pm 0.15(4)$ & $4.0 \pm 0.7(4)^{*}$ \\
$\mathrm{O}_{2}$ & $\left.6.3 \pm 1.8(9)^{\mathrm{b}}\right)$ & $2.6 \pm 0.4(4)^{*}$ \\
\hline
\end{tabular}

a) $\mu$ moles/g liver wet weight with standard deviation and number of contributing values

b) $\mu \mathrm{moles} / \mathrm{min} \cdot \mathrm{g}$ liver wet weight with standard deviation and number of contributing values

* These values differ significantly $(p<0.05)$ from their corresponding controls (t-test)

the intrahepatic concentration of fructose and fructose1-phosphate if fructose was added to the perfusion medium (Tab. 2).

5. Under all experimental conditions reported so far the intrahepatic ATP/ADP ratio was significantly decreased by 1-methyl-4-(3-methyl-5-isoxazolyl-)pyridinium chloride (Tab. 5).

6. The hepatic oxygen consumption and $\mathrm{CO}_{2}$ formation were reduced in the presence of this compound ( $\mathrm{Tab} .5$ ).

7. Recently we have reported that phenylethylbiguanide $(8,17)$ and butylbiguanide $(7)$ inhibited the uptake of potassium ions by the perfused liver. The same effect was now observed with 1-methyl-4-(3-methyl-5-isoxazolyl-)pyridinium chloride (Fig. 4). The uptake of phosphate ions was also reduced. Both effects may be related to the respiratory state and the intracellular ATP potential as discussed earlier (7).

8. In control experiments the $\mathrm{pH}$-value of the medium increased constantly after the addition of sodium lactate (Fig. 5). This effect was also observed in perfused rat livers and attributed by BücHER et al. (18) to the fact that lactate permeates the plasma membrane only as the uncharged molecule. Consequently, the 

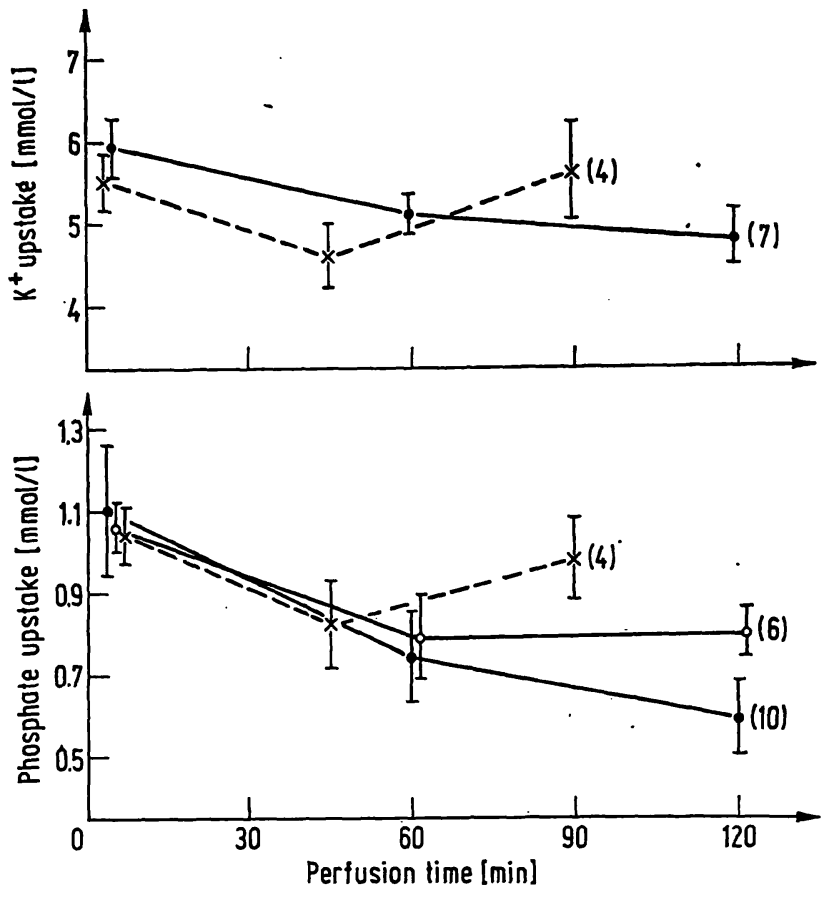

Fig. 4

The influence of 1-methyl-4-(3-methyl-5-isoxazolyl-)pyridinium chloride on the uptake of potassium and phosphate ions by perfused ginea pig livers. Substrate: lactate
gide on the uptake of potassium and phosphate

O-O $0.3 \mathrm{mmol} / 1 \mathrm{l}(\mathrm{n}=6), \times-\times 1.5 \mathrm{mmol} / \mathrm{l}(\mathrm{n}=4) \quad 1$-methyl-4(3-methyl-5-isoxazolyl-)pyridinium chloride, $0-0$ controls $(n=7$ for $\mathrm{K}^{+}, \mathrm{n}=10$ for phosphate). Vertical bars represent standard deviations

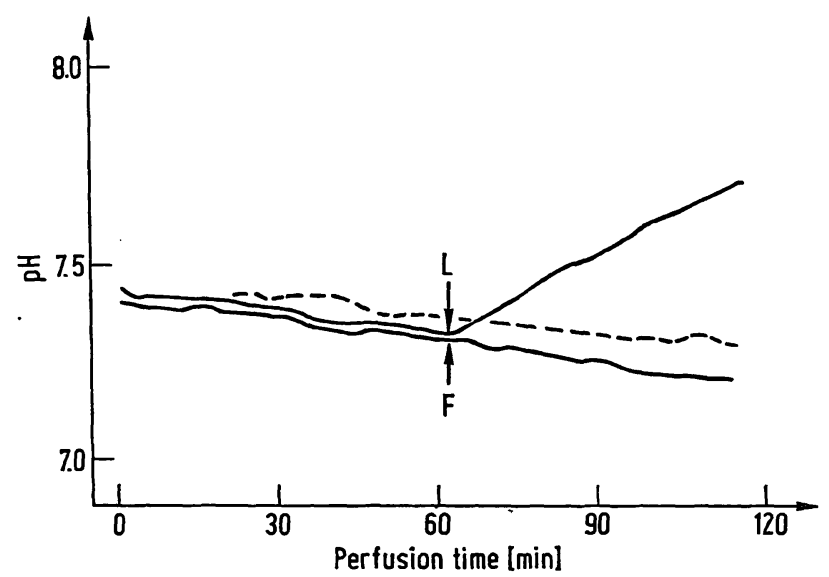

Fig. 5

Typical records of the perfusate $\mathrm{pH}$ values. In the two upper experiments $20 \mathrm{mmol} / 1$ of lactate was added after $60 \mathrm{~min}$ as indicated py arrow (L) and in one perfusion $1.5 \mathrm{mmol} / 1$ 1-methyl-4-(3-methyl-5isoaxolyl-)pyridinium chloride after $45 \mathrm{~min}$ (broken line). At the (F)

Tab. 6

The lactate consumption and glucose production in the period 75 to $90 \mathrm{~min}$ perfusion. Lactate $(12 \mathrm{mmol} / \mathrm{l})$ was added to the medium in all experiments. All values ( $\mu$ moles $/ \mathrm{min} \cdot \mathrm{g}$ liver wet weight) are means given with standard deviations and the number of contributing values in parentheses

\begin{tabular}{lcc}
$\begin{array}{c}\text { 1-Methyl-4-(3-methyl- } \\
\text { 5-isoxazolyl-)pyridi- } \\
\text { nium chloride }\end{array}$ & - & $1.5 \mathrm{mmol} / \mathrm{l}$ \\
\hline Lactate (used) & $2.09 \pm 0.56(6)$ & $0.31 \pm 0.29(5)$ \\
Glucose (formed) & $1.04 \pm 0.39(6)$ & $0.08 \pm 0.09(5)$ \\
Lactate (used) & 2.1 & 3.9 \\
\hline Glucose (formed) & &... \\
\hline
\end{tabular}

extracellular $\mathrm{H}^{+}$concentration is decreased. This effect was regarded as a possible basis for the therapeutic action of sodium lactate in the treatment of acidosis (19).

In the presence of 1-methyl-4(3-methyl-5-isoaxazolyl-) pyridinium chloride the hepatic utilization of lactate was inhibited (Tab. 6). Therefore, only a slight rise of the extracellular $\mathrm{pH}$-value occured under these conditions (Fig. 5).

\section{Discussion}

All reported effects of 1-methyl-4(3-methyl-5-isoxazolyl-)pyridinium chloride on the metabolism of perfused guinea pig livers have also been observed in the presence of phenylethylbiguanide. Therefore, we have suggested (4) that both agents act in the same way. Phenylethylbiguanide is a well known inhibitor of cell respiration $(20-22)$. This effect can also be demonstrated in the perfused guinea pig liver for the biguanide (8) and for 1-methyl-4(3-methyl-5-isoxazolyl-)pyridinium chloride (Tab. 5). As a consequence of the decreased respiration, reducing equivalents accumulate and the hepatic ATP/ADP ratio declines.

Several data indicate that the citric acid cycle was inhibited by 1-methyl-4(3-methyl-5-isoxazolyl-)pyridinium chloride:

1. A cross-over phenomenon between acetyl-Co A and citrate (Tab. 3). Consequently, the concentration of 2-oxoglutarate was lowered. This metabolite appeared to be a very sensitive indicator for the action of phenylethylbiguanide on hepatic metabolism $(8,17)$.

2. A decrease of the hepatic $\mathrm{CO}_{2}$ production (Tab. 5). These data and the accumulation of the hepatic pyruvate plus lactate concentration indicate that the pyruvate oxidation was reduced during the influence of 1-methyl-4(3-methyl-5-isoxazolyl-)pyridinium chloride. In addition, this compound affected the conversion of pyruvate and fructose to glucose.

In the guinea pig liver fructose enters the EMBDENMeYerhof pathway primarily at the level of the triose phosphates (14). The ratio fructose-1,6-diphosphate to fructose-6-phosphate was increased by 1-methyl-4(3methyl-5-isoxazolyl-)pyridinium chloride in the presence of lactate or fructose. However, the compound must have affected reactions before this step because the concentration of the triose phosphates were not elevated. The uptake of lactate was not inhibited since the intracellular concentrations of lactate plus pyruvate were increased in the presence of 1-methyl-4(3-methyl-5-isoxazolyl-)pyridinium chloride. A significant rise of pyruvate was apparently prevented by the concomitant accumulation of reducing equivalents. Therefore, the conversion of lactate to glucose must have been affected between pyruvate and phosphoenolpyruvate. A significant inhibition of one of the reactions between phosphoenolpyruvate and the triose phosphates presumably would have been detected by the pattern of hepatic metabolite concentrations. 
When fructose was used as substrate for gluconeogenesis the intrahepatic concentration of fructose rose and that of fructose-1-phosphate decreased in the presence of 1-methyl-4(3-methyl-5-isoxazolyl-)pyridinium chloride indicating that the fructokinase reaction (EC 2.7.1.3) was affected. This enzyme is very sensitive to an alteration of the intracellular ATP/ADP ratio $(23,24)$, which was depressed under the influence of 1-methyl-4(3-methyl-5isoxazolyl-)pyridinium chloride (Tab. 5).
The inhibitory effect of 1-methyl-4(3-methyl-5-isoxazolyl-)pyridinium chloride and phenylethylbiguanide on the hepatic glucose formation may at least partly explain their hypoglycemic action. Since both agents caused the same metabolite alterations these effects are not specific for either phenylethylbiguanide or 1methyl-4(3-methyl-5-isoxazolyl-)pyridinum chloride in the perfused guinea pig liver.

\section{References}

1. Bauer, V. J., Fanshawe, W. J., Dalelian, H. P. \& Safir, S. R. (1968), J. Med. Chem. 11, 984-986. - 2. RigGI, S. J., Blickens, D. A. \& Boshint, C. R. (1968), Diabetes 17, 646-647. 3. HAECKEL, R. (1972), Deut. Med. Wochenschr. 97, 388-394. 4. HAECKEx, R. (1971), 1. European meeting on the liver perfusion technique, Milano, July 16, in the press. - 5. MrLler, L. L., BLy, C. G., Watson, M. L. \& BALE, W. F. (1951), J. Exp. Med. 94, 431-442. - 6. Schmassex, H. (1963), Biochem. Z. 336, 460-467. - 7. Haeckel, R., Haeckel, H. \& ANDeReR, M. (1971), Biochem. Pharmacol. 20, 1053-1060. - 8. HAECKEL, R. \& Haeckex, H. (1972), Diabetologia 8, 117-124. - 9. Wollenderger, A., Krause, E. G. \& Mahler, B. E. (1958), Naturwissenschaften 45, 294-295. - 10. HAECKEL, R. (1972), this j. 10, 86-90. - 11. Gomort, G. (1953), Stand. Meth. Clin. Chem. 1, 84-87. - 12. Keppler, D. \& DeCKer (1970), Methoden der Enzymatischen Analyse (BERGMEYER, U., ed.), Verlag Chemie, Weinheim 1089-1094. - 13. НонORST, H. J., KREUTZ, F. H. \&
BÜCHER, TH. (1959), Biochem. Z. 332, 18-46. - 14. HAECKEL, R. (1973), Diabetologia, in press. - 15. Schachinger, H. \& Mold, W., in preparation. - 16. vaN SLYKE, D. D. \& PlazIN, J. (1961), Micromanometric Analysis, The Williams and Wilkins Comp., Baltimore, p. 46. - 17. HaECKex, R. \& Haecket, H. (1971), Regulation of Gluconeogenesis (SöLING, H. D. \& WILlms, B., ed.), G. Thieme Verlag, Stuttgart, 127-139. - 18. Bücher, Th., Brauser, B., Conze, A., Klein, F., Langguth, O. \& Sies, H. (1972), Eur. J. Biochem. 27, 301-317. - 19. Cohen, R. D., Iles, R. A., Barnett, D., Howell, N. E. O. \& Strunin, J. (1971), Clin. Science 41, 159-170. - 20. Hollunger, G. (1955), Acta Pharmacol. Toxicol. 11, Suppl. 1, 1-84. - 21. SCHÄFER, G. (1964), Biochim. Biophys. Acta 93, 279-283. - 22. Davidopf, F. (1968), J. Clin. Invest. 2331-2343. - 23. PARKs, R. E., BENGershom, E. \& Lardy, H. A. (1957), J. Biol. Chem. 227, 231-242. 24. Sanchez, J. J., Gonzales, N. S. \& Pontis, H. G. (1971), Biochim. Biophys. Acta 227, 67-78.

Priv.-Doz. Dr. R. Haeckel D-3 Hannover Karl-Wiechert-Allee 9 